
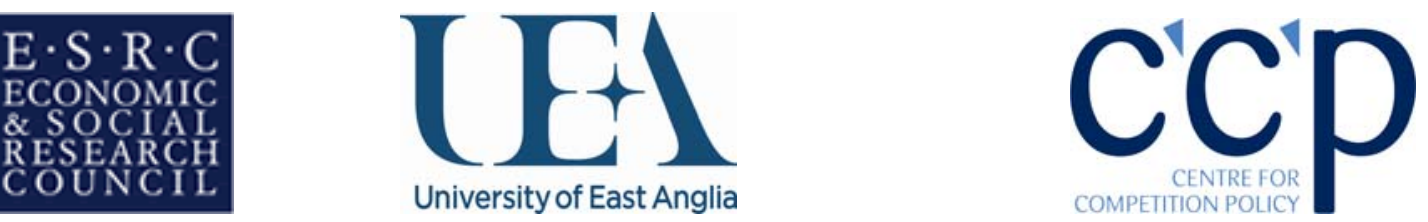

\title{
The UK Cartel Offence: Lame Duck or Black Mamba?
}

\author{
by \\ Andreas Stephan \\ ESRC Centre for Competition Policy \& Norwich Law School, \\ University of East Anglia
}

\section{CCP Working Paper 08-19}

\begin{abstract}
A criminal offence requiring Ghosh dishonesty was introduced in the UK by the Enterprise Act 2002, primarily to enhance cartel deterrence as a complement to corporate fines. Yet the first convictions resulted from a US plea bargain in 2008. This paper identifies three obstacles to enhancing deterrence through the cartel offence. First, Norris v USA and a public survey suggest relatively weak perceptions of cartels persist in the UK. It was envisaged that convictions would remedy this, but prosecutors will continue to be very selective about the cases they bring to trial if there are doubts as to whether price fixing alone is viewed as objectively dishonest. Secondly, any increase in criminal enforcement risks discouraging leniency applications to the European Commission, because corporate immunity granted on the Community level does not automatically protect employees from criminal prosecution in national courts. There is also no conclusive mechanism for direct settlement, as there is in the US. Thirdly, sizeable benefits and purportedly low detection rates mean deterrence may be weak if custodial sentences do not become the norm. Further sanctions such as Director Disqualification Orders can play an important role in ensuring cartelists do not seek immediate reemployment at a high level.
\end{abstract}

November 2008 
JEL Classification Codes: K14, K21, L40, L41

Keywords: Cartel offence; deterrence; dishonesty; Enterprise Act 2002; Norris v USA

\section{Acknowledgements:}

The support of the UK's Economic and Social Research Council (ESRC) and Arts and Humanities Research Council (AHRC) is gratefully acknowledged. The author would also like to thank Morten Hviid, Christopher Harding (Aberystwyth), Angus MacCulloch (Lancaster), Caron Beaton-Wells (Melbourne Law School) and Brent Fisse (Brent Fisse Lawyers, Sydney) for helpful comments.

\section{Contact details:}

Andreas Stephan, ESRC Centre for Competition Policy, University of East Anglia, Norwich, NR4 7TJ, UK.

a.stephan@uea.ac.uk 


\section{Introduction}

The Criminal Cartel Offence was adopted in the UK to enhance deterrence in cartel enforcement. Under s.190 Enterprise Act 2002, an individual who 'dishonestly' agrees to cartel conduct such as price fixing, can face imprisonment for up to five years, and/or an unlimited fine. This marks a remarkable criminalisation of cartel conduct in the UK, which - prior to the Competition Act 1998 - was subject to only a regulatory slap on the wrist. The most serious cartel infringements are pursued on the Community level by the European Commission D-G Competition, in breach of Article 81 EC. However, the only available sanction that exists is administrative fines on corporations under Regulation 1/2003 (preceded by Regulation 17/62). These are subject to a statutory ten per cent cap of an undertaking's worldwide turnover, intended to protect firms from the adverse effects of high fines. ${ }^{1}$ The White Paper that preceded the Enterprise Act recognised this cap might prevent the imposition of fines of sufficient magnitude to deter cartel infringements being committed, given their likelihood of detection. ${ }^{2}$ The criminal offence promised to compensate for this shortfall in deterrence, potentially complementing cartel enforcement on both the UK and Community levels. However, five years after the offence came into force in the UK, the first convictions resulted from guilty pleas induced by a US plea bargain. ${ }^{3}$ On Wednesday 11 June 2008 Bryan Allison, David Brammer and Peter Whittle were jailed for between thirty months and three years for their roles in organising a worldwide cartel in the supply of flexible marine hoses. The three individuals were arrested by US antitrust authorities in Houston in 2007, after they attended a cartel meeting. They admitted guilt in the US and agreed jail sentences under a plea bargain. However, the US Department of Justice Antitrust Division (DOJ) allowed them to return to the UK on condition that they plead guilty to the UK cartel offence,

\footnotetext{
${ }^{1}$ Musique Diffusion Francaise SA, C. Melchers \& Co., Pioneer Electronic (Europe) NV and Pioneer High Fidelity (GB) Limited v. E.C. Commission (Cases 100-103/80) [1983] 3 CMLR 221, at 265; the ten per cent cap also exists in the UK under s.36(8) Competition Act 1998

2 Department of Trade and Industry (DTI), A World Class Competition Regime. Cm 5233. (2001) London: The Stationery Office CM 5233, at 7.13-7.18

${ }^{3}$ OFT Press Release, 'Three imprisoned in first OFT criminal prosecution for bid-rigging' (11 June 2008); OFT Press Release, 'OFT brings criminal charges in international bid rigging, price fixing and market allocation cartel' (19 December 2007); S D Hammond, 'Recent developments, trends, and milestones in the Antitrust Division's criminal enforcement program' unpublished paper. Presented at $56^{\text {th }}$ Annual Spring Meeting, ABA Section of Antitrust Law. Washington, DC. 26 March 2008 at 18-19
} 
and that they would return to the US if their UK sentences were shorter than those agreed under the plea agreement. The only other convictions pending concern four former British Airways executives involved in the price fixing of passenger fuel surcharges. These individuals are also likely to plead guilty to ensure they are not extradited to the US. The DOJ had already imprisoned another BA executive, Keith Packer, in October 2008 for a parallel offence relating to air cargo fuel surcharges. ${ }^{4}$ The cartel offence's first real test - a hard fought 'original' prosecution brought by the Office of Fair Trading (OFT) or Serious Fraud Office (SFO) - thus still remains elusive. ${ }^{5}$

This paper identifies three obstacles to increasing the number of convictions under the cartel offence and ensuring they have a deterrent effect. These follow an outline of the arguments in favour of punishing individuals responsible for collusion, as well as their companies (Part 2). First, the potential difficulties of securing a conviction in the UK under the 'dishonesty' standard (Part 3). The House of Lords ruling in Norris v United States highlights the historical tolerance of cartels. In addition, a public survey designed by this author and conducted by YouGov reveals relatively weak public perceptions of price fixing in Britain and in particular - low support for imprisonment as a sanction. Convictions are thought to be important in hardening popular attitudes, but the UK offence may be flawed in relying so heavily on a contemporary judgement of dishonesty. Prosecutors may continue to be very selective in bringing cases to trial if there is doubt as to whether price fixing is objectively dishonest according to 'the standards of reasonable and honest people'. Secondly, immunity granted by the European Commission to a revealing firm does not automatically protect employees from criminal prosecution on the national level (Part 4). Efforts to step up enforcement without such an arrangement may actually discourage firms from self-reporting and negatively impact the number of infringements uncovered. Moreover, the absence of a conclusive mechanism for direct settlement means that every case must go to trial. In the US, a high number of

\footnotetext{
${ }^{4}$ DOJ Press Release, 'Former British Airways Executive Agrees to Plead Guilty to Participating in PriceFixing Conspiracy in Air Cargo Shipments' (30 September 2008) http://www.usdoj.gov/atr/public/press releases/2008/237809.pdf accessed 20 Oct 2008

${ }^{5}$ Prosecutions of the cartel offence in England and Wales, and in Northern Ireland are generally undertaken by the SFO. Prosecutions in Scotland are brought by the Lord Advocate
} 
cases are completed each year thanks to plea bargains which allow defendants to negotiate their penalty in return for a swift settlement in lieu of trial. Thirdly, given the sizeable benefits from a cartel and the purportedly low detection rates, the deterrent effect of the offence may be weakened if custodial sentences do not become the norm (Part 5). Further sanctions such as Director Disqualification Orders can play an important role in ensuring cartelists do not seek immediate reemployment at a high level. Concluding remarks round off the paper in Part 6.

\section{Deterrence: Ensuring the Right People are Punished}

Conventional economic literature on deterrence assumes that infringing firms are rational economic actors. Before making the decision to form or enter a cartel, they weigh the expected benefits of collusion against the expected costs. Deterrence under this paradigm is achieved where the expected likelihood and magnitude of punishment outweighs the expected cartel profits. ${ }^{6}$ Leniency programmes go some way towards raising detection rates by inducing the selfreporting of infringements in return for immunity to the first firm only. Beyond this however, increased detection requires costly expenditure on investigations. It is thus easier to simply increase the punishment; something that also makes self-reporting for immunity more likely. There are, however, a number of reasons why effective deterrence cannot be achieved through corporate fines alone.

\footnotetext{
${ }^{6}$ There is a wealth of deterrence literature consistent with the premise that cartelists will undertake a rational balancing of expected benefits and likely costs before committing an infringement: JM Connor and RH Lande, 'The size of cartel overcharges: Implications for US and EU fining policies' (2006) The Antitrust Bulletin 51:4, 983; WPJ Wils, Efficiency and Justice in European Antitrust Enforcement (Hart Publishing, Oxford 2008) Ch 6; G S Becker, 'Crime and Punishment: An Economic Approach' 1968) Journal of Political Economy 16 (2), 169. Strictly speaking, Becker's model (and those based on it) requires that sanctions be calculated according to the harm caused, rather than the gain earned. However, the difficulties of calculating this with any accuracy have caused some advocates of Becker to accept gain as a more realistic substitute: R A Posner, Antitrust Law (2 ${ }^{\text {nd }}$ Edn UCP, Chicago 2001) at 259; discussed in P Manzini, 'European Antitrust in Search of the Perfect Fine' (2008) World Competition 31(1) 3-17 at 5. Deterrence does not require offenders to be entirely rational, they need only consider the costs and benefits to some degree: RGV Clarke, 'Situational Crime Prevention' (1995) Crime and Justice: A Review of Research 19:91-150. Even the most critical opponents of economic deterrence paradigms do not rule out the effect of cost-benefit deterrence entirely: E Sutherland and D Cressey, Principles of Criminology $\left(6^{\text {th }}\right.$ edn Philadelphia: Lippincott 1960) 288-289; discussed in A Von Hirsch et al., Criminal Deterrence and Sentence Severity: an analysis of recent research (Hart, Oxford 1999) at 11
} 
First, there is a limit to how high fines can go. In recognition of the fact that strong sanctions are necessary, the European Commission has steadily increased the levels of fines imposed for cartel infringements. In the first quarter of 2007, fines in excess of $€ 1.6$ billion were imposed pursuant to just two infringements alone. However, fines both in the UK and on the Community level are subject to the ten per cent worldwide turnover cap. With the proportion of cartels caught likely to be low, fines not exceeding this ten per cent ceiling may not be sufficient, leaving a shortfall in cartel deterrence. ${ }^{7}$ Even if the ten per cent cap were removed, fines high enough to achieve effective deterrence may bankrupt some firms. This is an undesirable outcome for competition authorities because it will result in a more concentrated market and impose social costs, as well as being politically unacceptable. ${ }^{8}$ Encouraging private actions for damages entails the same danger. Corporate fines thus need to be complemented with other sanctions.

Secondly, it is individuals - not companies - who make the decision to collude. The deterrence model described above assumes that the decision to form or join a cartel is made at the top level, with the corporation's profit maximising interests at heart. This may not always be true; some company executives may collude simply to avoid the uncertainties and dangers of competition or to survive an economic downturn. Moreover, although the most serious cartel infringements were coordinated at the top level, the British Airways/Virgin fuel surcharge case highlights the danger of infringements being committed by rogue marketing officials or subsidiaries. ${ }^{9}$ Even where collusion occurs at the top level, it is unlikely that the decision to form a cartel is taken within the institutionalised corporate decision making processes of the firm - particularly as awareness of competition laws improves, and compliance programmes become more sophisticated and widespread. As Moran argues in relation to fraud, the 'smoked filled room' image is a highly apt forum for corporate

\footnotetext{
${ }^{7}$ A Stephan, 'The Bankruptcy Wildcard in Cartel Cases' (2006) JBL, August Issue, 511-534; WPJ Wils, The Optimal Enforcement of EC Antitrust Law: Essays in Law and Economics (Kluwer Law International, The Hague 2002) at 39; P G Bryant and E W Eckard, 'Price Fixing: The Probability of Getting Caught' (1991) Review of Economics and Statistics 73 (3), 531

See generally: Stephan, above $\mathrm{n} 7$

${ }^{9}$ OFT Press Release, 'British Airways to pay record $£ 121.5 \mathrm{~m}$ penalty in price fixing investigation' (01 August 2007); Appendix 1of this paper gives some indication of the positions price fixers typically hold within undertakings
} 
criminality, since firms as structured institutions or bureaucracies are in their nature rule-following entities. ${ }^{10}$

Thirdly, corporate fines do not directly punish the individuals responsible for price fixing. These individuals are unlikely to desist from collusive behaviour where the consequences of their actions will be felt by the corporation as a whole. ${ }^{11}$ It is the firm that largely bears the risk of detection and punishment, not the individual. Indeed, by the time corporate fines are imposed by the Competition Authority, these individuals may work for another company or have retired. Similarly, many shareholders who benefited from the spoils of the collusive period, albeit unknowingly, may have sold their shares and moved on. Corporate fines will have the greatest impact on profits, and so current shareholders and employees will suffer. It can be argued that corporate fines force companies to police themselves and ensure they have effective compliance programmes in place. ${ }^{12}$ To some extent this is true and fines constitute an effective incentive for such self-regulation. However, recent price fixing cases involving BA and Shell demonstrate that individuals and subsidiaries can slip through the net, even where apparently rigorous compliance efforts are maintained. ${ }^{13}$ In addition, as Whelan points out, if the only sanction that is imposed is high fines on firms, then there may be a disincentive for those firms to maintain an effective compliance programme. ${ }^{14}$ The less the firm knows the better, because a rigorous compliance programme risks uncovering more culpability. On the other hand, regulators should not only punish individuals but also the undertakings, as this may lead to senior executives forcing scapegoat employees to bear the risk of their illegal behaviour.

\footnotetext{
${ }^{10}$ M Moran, 'Investor Protection and the Culture of Capitalism' in L Hancher \& M Moran (eds.), Capitalism Culture, and Economic Regulation (OUP, Oxford 1989)

${ }^{11}$ Parent companies are generally responsible for infringements committed by subsidiaries even if they were not directly involved, or were even aware, of the conduct

12 There may be scope under s.260 ('Derivative Claims') of the Companies Act 2006, for shareholders to sue company directors for 'an actual or proposed act or omission involving negligence, default, breach of duty, or breach of trust'. However, the general rule in Company Law has been: if the wrong has been done by the company, it is for the company to sue (Foss v Harbottle [1843] 2 Hare 461) and thus a resolution would probably have to be passed at the General Meeting for the firm to sue the company directors, without the direct involvement of shareholders. Moreover, under s.233 a company can purchase and maintain insurance against the director's liability

${ }_{13}$ European Commission Press Release, 13 Sep 2006. IP/06/1179

${ }^{14}$ See generally: $P$ Whelan, 'A principled argument for personal criminal sanctions as punishment under EC cartel law' 4 Competition Law Review 1, 7-40
} 
There is thus a strong argument for adopting sanctions that target the individuals responsible for cartels, as a complement to corporate fines. ${ }^{15}$ The UK, Canada and Ireland (among others) have followed the US example by adopting a criminal offence under which even senior executives of corporations face imprisonment and personal fines, as punishment for cartel behaviour. Australia and South Africa are the latest jurisdictions in the process of adopting such criminal sanctions. It is not easy to empirically measure the extent to which criminal sanctions enhance deterrence. However, the stepped up use of leniency and criminal enforcement in the US has resulted in many more cases coming to light, indicating that more cartel agreements are becoming unsustainable in reaction to the increasingly stark difference between immunity and sanction. ${ }^{16}$

\section{Is Price Fixing Dishonest?}

In order to enhance deterrence, it is not enough for a criminal offence to simply lay dormant in statute; it must be enforced and be seen to be enforced effectively. ${ }^{17}$ The White Paper stated that the UK offence must be '...actively applied so that its deterrent effect is genuinely felt.... ${ }^{18}$ The Penrose Report, prepared for the OFT in 2001, predicted some six to ten prosecutions a year be

\footnotetext{
${ }^{15}$ For more detailed arguments of why imprisonment is needed, see: SD Hammond, 'Charting New Waters in International Cartel Prosecutions' (Speech delivered to $20^{\text {th }}$ Annual National Institute of White Collar Crime, San Francisco. March 2006) http://www.usdoj.gov/atr/public/speeches/214861.htm 20 Oct 2008; P Massey, 'Criminal Sanctions for Competition Law: A Review of Irish Experience' (2004) Competition Law Review 1(1) 23-40; N Wehmhörner, 'Optimal pecuniary sanctions and the US sentencing and EU fining guidelines' in Cseres, Schinkel and Vogelaar (eds.), Criminalization of Competition Law Enforcement: Economic and Legal Implications for the EU Member States (London: Edward Elgar, 2006); see also OECD 'Fighting Hard Core Cartels: Harm, Effective Sanctions and Leniency Programmes' (2002) Reports to the Organization for Economic Co-Operation \& Development: http://www.oecd.org/dataoecd/41/44/1841891.pdf accessed 20 Oct 2008, for an overview of jurisdictions who have adopted, or are in the process of adopting, criminal offences

${ }^{16}$ See for example caseload statistics in Hammond, above $\mathrm{n} 3$

17 A number of studies suggest the risk of punishment has a far greater impact on deterrence than the severity of punishment: PA Langan and DP Farrington, Crime and Justice in the United States and England and Wales, 1981-86 (Bureau of Justice Statistics, Washington D.C. 1998); HL Ross, Confronting Drunk Driving (Yale University Press, Connecticut 1992) 73; R Paternoster, 'The deterrent effect of the perceived certainty and severity of punishment' (1987) Justice Quarterly 4: 173-217; D Beyleveld, A Bibliography on General Deterrence (Saxon House, Farnborough 1980); Von Hirsch et al., above n 6 at 26 ${ }^{18}$ DTI White Paper, above n 2 at 7.33
} 
brought under the new cartel offence. ${ }^{19}$ The lack of convictions thus far may reflect how the offence does not apply retrospectively and thus only captures infringements committed since June 2003. However, the failure to bring more cartelists before the courts may also reflect anxieties over the requisite standard of dishonesty.

Under s.188 Enterprise Act, an individual is guilty of the criminal offence if he or she 'dishonestly agrees with one or more other persons to make or implement, or to cause to be made or implemented' any of the arrangements defined in s.188(2) relating to at least two undertakings. The dishonesty standard pursuant to the offence is that set out in $R \vee$ Ghosh. ${ }^{20}$ In order for an individual to be convicted, a jury must determine that a two-part objective/subjective test is satisfied:

1. ... according to the ordinary standards of reasonable and honest people what was done was dishonest. [If it was not dishonest, the test is not satisfied]

2. [and] ...the defendant himself must have realised that what he was doing was by those standards dishonest. ${ }^{21}$

The White Paper acknowledged that 'a defendant could use as his defence the claim that he honestly believed he was acting in accordance with Article $81 \mathrm{EC}$ or Chapter I [Competition Act 1998]'. ${ }^{22}$ In discussing the morality of cartel infringements, MacCulloch notes the danger of defendants using the 'Robin Hood defence'; for example when a crisis cartel is formed in a failing industry. ${ }^{23}$ The second limb of the dishonesty test hinges on whether a defendant knew what they were doing was dishonest by the standards of ordinary and reasonable people. It is not whether the defendant was reckless as to whether they were dishonest, or whether they should have known that it was

\footnotetext{
${ }^{19}$ A Hammond and R Penrose, The proposed Criminalisation of cartels in the UK. A report prepared for the Office of Fair Trading (November 2001) [2002] UKCLR 97; M Furse and S Nash, The Cartel Offence (Hart Publishing, Oxford 2004) at 3.6-3.7

20 [1982] 2 ALL ER 689

${ }^{21}$ lbid. at 696

22 White Paper, above $\mathrm{n} 2$ at 7.31

${ }^{23}$ A MacCulloch, 'Honesty, Morality and the Cartel Offence' (2007) ECLR 28(6), 355-363; Furse and Nash, above $\mathrm{n} 18$ at 12
} 
dishonest. ${ }^{24}$ Thus if the purpose of the cartel was to keep a firm solvent and prevent its employees becoming redundant, then the second leg of the dishonesty test may not be satisfied. This defence is only likely to succeed if the agreement was short in duration and the OFT/SFO are unable to produce evidence that the individual tried to hide cartel meetings or knew that such behaviour was illegal. ${ }^{25}$ Harding and Joshua observe a 'spiral of delinquency' in that the more they hid the agreement, the more they must have known it was wrong. ${ }^{26}$ Subjective dishonesty may also be inferred from the breach of a compliance programme in which cartel behaviour is explicitly viewed as a dishonest practice by the firm.

The discussion that follows questions the ease with which a prosecutor can convince jurors that price fixing is objectively dishonest (according to the ordinary standards of reasonable and honest people); the first limb of the dishonesty test. ${ }^{27}$ The Penrose report acknowledged that 'the approach of 'dishonesty' may be difficult for juries to understand' in the context of cartel offences. ${ }^{28}$ On the one hand, prosecutors may not have any difficulty persuading jurors of the gravity of cartel offences, especially given that they were explicitly criminalised by Parliament in the 2002 Act. On the other, cartel offences are unique in having been historically tolerated in English law and treated tamely by successive British governments. Nowhere is this summarised more succinctly than in the House of Lords ruling in Norris v United States and others, in which secret price fixing committed as recently as 2000 was found to not be dishonest in common law unless accompanied by aggravating features such as fraud. Norris demonstrates why the seriousness of the cartel offence may not yet be adequately reflected in public opinion, as confirmed by a public survey from the ESRC Centre for Competition Policy. The danger is that the cartel offence is viewed as lacking legitimacy and that prosecutors are discouraged from bringing more cases to trial, because of doubts as to whether

\footnotetext{
${ }^{24}$ B Fisse, 'Cartel Offence: Dishonesty?' (2007) 35 Australian Business Law Review 235, at 262

${ }^{25}$ MacCulloch, above $\mathrm{n} 23$ at 358

${ }^{26} \mathrm{C}$ Harding and J Joshua, Regulating Cartels in Europe: A Study of Legal Control of Corporate Delinquency (Oxford: OUP, 2003) p.51

${ }^{27}$ The likelihood of differing judgements about the dishonesty standard of reasonable and honest people between different groups is acknowledged in Law Commission Consultation Paper No 155, Legislating the Criminal Code: Fraud and Deception 1999 at 5.11-5.14; Fisse, above n 23 at 4.2

${ }^{28}$ Penrose Report, above n 19 at 2.5
} 
price fixing itself is dishonest according to the standards of 'honest and reasonable people'.

\subsection{Norris v United States}

On 12 March 2008, the House of Lords ${ }^{29}$ - in overturning an earlier decision by the Divisional Court ${ }^{30}$ - found that secret price fixing alone was not in itself dishonest (and thus could not constitute conspiracy to defraud) unless it was accompanied by 'aggravating features', other than simply concealing the agreement. $^{31}$ The case concerned a former CEO of Morgan Crucible, Ian Norris, who was indicted by a US court in October 2003 for involvement in the price fixing of carbon products which took place between late 1989 and May 2000. The US Department of Justice Antitrust Division (DOJ) subsequently commenced extradition proceedings under the controversial Extradition Act 2003. ${ }^{32}$ S.137(2)(b) of the Act requires 'dual criminality' meaning that, '[the alleged] conduct would constitute an offence under the law of the relevant part of the United Kingdom punishable with imprisonment or another form of detention for a term of 12 months or a greater punishment if it occurred in that part of the United Kingdom'.

As the alleged crime was committed before June 2003, the dual criminality requirement was not satisfied by Part 6 of the Enterprise Act and so conspiracy to defraud was relied upon instead. The SFO had also begun criminal proceedings for conspiracy to defraud against nine individuals and five companies, for price fixing in sales to the NHS of the blood thinning drug warfarin between 1996 and 2000. ${ }^{33}$ Both the SFO and Goldshield Group (Plc), one of the principal companies involved in the NHS case, acted as intervening parties in the present extradition case, each aiding the legal counsel of the

\footnotetext{
${ }^{29}$ Norris v Government of the United States of America and others [2008] UKHL 16

${ }^{30}$ Norris v Government of the United States of America and others [2007] EWHC 71

${ }^{31}$ 'Conspiracy to defraud' is a broad English Common law offence against an agreement to do something prejudicial to another

32 The Extradition Act 2003 is controversial because, unlike the previous extradition treaty which required prima facie evidence of a crime, the 2003 Act requires only 'information'. Under s.84(7) it is effectively the US court (not a UK judge) who decides whether the evidence forwarded by the prosecution is sufficient to warrant a trial; Norris v USA, above n 29 at 33

${ }^{33}$ The SFO's investigations into price fixing of generic drugs is known as 'Operation Holbein': E.g. H Power 'Holbein shows the way' Telegraph, London. July 15, 2007; S Lister 'Drug chiefs on price-fixing charges' The Times, London. 6 April 2006
} 
United States and Ian Norris respectively. According to a 2005 article by Lever and Pike, a cartel agreement could constitute conspiracy to defraud, if it 'involves the use of dishonest means and prejudices, or carries a risk of prejudice to, another's rights, to the knowledge of the parties to the agreement that they had no right to do so..., 34

Norris' defence team argued that secret price fixing was not itself a crime in the UK prior to the Enterprise Act 2002. Making reference to a number of civil cases from the $19^{\text {th }}$ and $20^{\text {th }}$ centuries, they demonstrated that anticompetitive agreements had never been treated as dishonest or criminal in common law. In fact the case law showed a general tolerance of such agreements. For example, in Adelaide Steamship it was held that:

...no contract was ever an offence at common law merely because it was in restraint of trade... The right of an individual to carry on his trade or business in the manner he considers best in his own interests involves the right of combining with others in a common course of action, provided such common course of action is undertaken with a single view to the interests of the combining parties and not with a view to injure others. ${ }^{35}$

Moreover, in Jones $\mathrm{v}$ North, Sir James Bacon V-C ruled that there was no dishonesty in the act of bid-rigging, describing it as 'very honest'. ${ }^{36}$ Norris contended that in light of such decisions, (objective) dishonesty required something more than simply the secretive characteristics of the price fixing agreement - that some 'positive deception' had to be present. ${ }^{37}$

In the Divisional Court, Auld LJ rejected this view as questionable and accepted the US counsel's contention that such agreements have been regarded very

\footnotetext{
$34 \mathrm{~J}$ Lever and J Pike, 'Cartel Agreements, Criminal Conspiracy and the Statutory 'Cartel Offence': Parts I \& II' (2005) ECLR 26(2), 90 at 93; Welham v DPP [1961] A.C. 103 (HL); Lever \& Pike definition of conspiracy defraud as applied to price fixing was adopted by the Divisional Court in Norris v USA, above $\mathrm{n}$ 30 at 68

${ }^{35}$ Attorney General of the Commonwealth of Australia v Adelaide Steamship Co Ltd [1913] AC 781, at 797; Mogul Steamship Co Ltd v McGregor, Gow \& Co (1888) 21 QBD 544; (1889) 23; QBD 598 (CA); [1892] AC 25

36 Jones v North (1875) LR $19 \mathrm{Eq}$ at 426 and 429

${ }^{37}$ Norris v USA, above n 29 at 54; R v De Berenger (1814) 3 M \& S 67; Scott v Brown, Doering, McNab \& Co [1892] 2 QB 724; see also C Munro and C Cooper 'Wanted! (for conspiracy)' The Journal April 2007, 22
} 
differently in the more recent past - especially since the Second World War. ${ }^{38}$ He held that:

'the critical point is not one of law as to the applicability or otherwise of the common law offence of conspiracy to defraud to price fixing agreements, but one of fact or evaluation on a case by case basis as to the presence of dishonesty, as in most cases of alleged fraud'. ${ }^{39}$

Moreover, Auld LJ took the view that dishonesty could largely be inferred from the defendant's efforts to keep the cartel secretive. Adopting the reasoning in Lever \& Pike's paper, he noted:

The difference in law between deceiving potential customers by secrecy and some other form of dishonesty is difficult to discern. And, as a sharp distinction of fact, rather than one of degree and evaluation depending on the circumstances, a jury would be hard-put to see much sense in it. ${ }^{40} \ldots$.. The greater the efforts of the parties to a cartel to keep it secret, the more readily a jury might infer: that the intention of the cartelists was to preserve an illusion that they were engaged in normal and bona fide competition with each other ...that the cartelists had an actual and dishonest appreciation that loss or risk of possible loss by counterparties would, or was likely to, follow from the cartelists' conduct: see Wai Yu-tsang v The Queen [1992] 1 AC $269 .{ }^{41}$

When the Norris case was appealed to the House of Lords, the Divisional Court's decision was overturned. Making reference to appeal decisions in Mogul Steamship, ${ }^{42}$ as well as decisions in Adelaide Steamship Co Ltd, ${ }^{43}$ North Western Salt Co $\mathrm{Ltd}^{44}$ and Rawlings ${ }^{45}$ the Lords found: '...unless there were aggravating features such as fraud, misrepresentation, violence, intimidation or inducement of a breach of contract, [cartel] agreements were not actionable or indictable'. ${ }^{46}$ They identified the justifications for this approach in common law. These very much reflect the prevailing attitudes towards cartel practices in the previous two centuries. They include the purported benefits of some restraints of trade such as 'preventing cut-throat competition... [or the] lowering of wages

\footnotetext{
${ }^{38}$ Norris v USA, above $\mathrm{n} 30$ at 50

${ }^{39}$ Ibid. at 55

${ }^{40}$ Norris v USA, above $\mathrm{n} 30$ at 66-67

${ }^{41}$ Ibid. at 67-68; Lever and Pike, above n 34 at 95

${ }^{42}$ Mogul Steamship Co Ltd v McGregor, Gow \& Co, above n 35

${ }^{43}$ Adelaide Steamship, above $\mathrm{n} 35$

${ }_{44}^{44}$ North Western Salt Co Ltd v Electrolytic Alkali Co Ltd [1913] 3 KB 422

${ }^{45}$ Rawlings v General Trading Co [1921] 1 KB 635

${ }^{46}$ Norris v USA, above $\mathrm{n} 29$ at 17
} 
or unemployment', and how courts are ill-placed to judge whether such a practice is against the public interest. The Lords also pointed to a distinction between the malicious object of injuring another party, and the promoting of personal business interests: 'While commercial parties could not lawfully act with the wrongful and malicious object of injuring another party, they were free to promote their own business as they thought fit, 'however severe and egotistical' 47 such means might be, even though this might inflict loss to others'. 48 This distinction is questionable in light of modern economic theory, according to which the pricing decisions of businesses directly affect the welfare of consumers.

In light of this distinction, the Lords pointed out that secrecy alone could not satisfy the (objective) dishonesty standard. It is the act that causes the loss which must be treated as dishonest, and price fixing was not considered so: 'there are problems with the notion that mere secrecy can of itself render the price-fixing agreement criminal. It is not as if secrecy is always necessary for a price-fixing agreement to be effective, or that it is the secrecy which causes a purchaser loss ...it must be the alleged dishonesty which causes the loss'. ${ }^{49}$ The view expressed by Auld LJ - that the central issue was not one of law as to the applicability of conspiracy to defraud to cartel agreements, but a practical assessment on a case by case basis as to the presence of dishonesty - was also rejected. The Lords pointed to the fundamental requirement of certainty in criminal law, ${ }^{50}$ and to the fact that the decisions in Jones $v$ North and Mogul Steamship, in support of the contention that agreements to fix prices had not been treated as being in themselves dishonest, had never been overruled. ${ }^{51}$

In support of this view, they also pointed to the exclusively civil treatment of price fixing in legislation preceding the Enterprise Act $2002 .^{52}$ Under the

\footnotetext{
${ }_{47}^{47}$ Mogul Steamship Co Ltd v McGregor, Gow \& Co, above n 42 at 552-553

${ }^{48}$ Norris v USA, above $\mathrm{n} 29$ at 17

${ }^{49}$ Norris v USA, above $\mathrm{n} 29$ at 60

${ }^{50}$ Ibid. at 52-62; $R$ v Rimmington [2006] 1 AC 459; $R$ v Jones [2007] 1 AC 136

$51 \mathrm{lbid}$. at 20; They also pointed to the more recent decision in British Airways Board $v$ Laker Airways Ltd [1985] AC 58, at 79 (not referred to by the divisional court) in which a predatory price fixing arrangement alleged against British Airways and British Caledonian gave Laker no cause of action which it could have pursued in the English court

${ }^{52}$ Norris v USA, above n 29 at $24-44$
} 
Restrictive Practices Act 1948, cartels were tolerated, unless found to operate against the public interest by the Monopolies Commission, upon reference by the Secretary of State. In 1955, the government rejected the majority recommendation in the Cairns Committee Report for criminalisation of cartel conduct, accepting the minority view that criminalisation was inappropriate because some cartels operated in the public interest. ${ }^{53}$ Cartel enforcement remained a purely civil matter prior to the 2002 Act; section 35(2) of the Restrictive Trade Practices Act 1976 specifically stated that 'no criminal proceedings lie against any person' for contravention of the Act. ${ }^{54}$ It is also clear from the content of the Enterprise Act (in 'creat[ing]' an offence), from the Penrose Report (in recognising that only undertakings were previously subject to penalties), and from the relevant parliamentary debates, that no criminal provision for cartel activity existed prior to the 2002 Act. ${ }^{55}$ The minister responsible had even given assurances in Parliament that there was no prospect of Anthony Tennant being extradited because '...the matter is not defined as criminality at this point'. ${ }^{56}$ Tennant, a former executive at Christies, is alleged to have initiated the price fixing of auction house fees in the 1990s, along with Sotheby's boss Alfred Taubman who was convicted and imprisoned in the US. Finally, it was pointed out how it would be strange for Parliament to restrict the statutory offence to individuals involved in horizontal agreements only, with a maximum penalty of 5 years imprisonment, when a price fixing offence of conspiracy to defraud could be applied to undertakings, to vertical agreements and carried a maximum penalty of 10 years imprisonment. ${ }^{57}$

The Lords went on to reject the argument that, 'even accepting that operating a price-fixing cartel did not constitute an offence for much of the $20^{\text {th }}$ century, public perceptions had changed by the end of the 1980s so as to justify taking a contrary position'. 58 'It is impossible to find any contemporaneous observations

\footnotetext{
53 'Collective Discrimination: A Report on Exclusive Dealing, Collective Boycotts, Aggregated Rebates and Other Discriminatory Trade Practices' Cmd 9504 (HMSO, London 1955) at 242-259 http://www.competition-commission.org.uk/rep pub/reports/1950 1959/010collective.htm accessed 20 Oct 2008

54 The only offence was failure to comply with a request from the Director General of Fair Trading under S.37(1)

${ }^{55}$ Penrose Report, above $\mathrm{n} 19$ at 6.1 ; Norris $v$ USA, above $\mathrm{n} 29$ at 40

${ }^{56}$ Norris v USA, above $\mathrm{n} 29$ at 42

${ }^{57}$ Section 12(3) of the Criminal Justice Act 1987

${ }^{58}$ Norris v USA, above n 29 at 57
} 
to support the argument, at least in the material made available in this case ...However, even if there had been a discernible shift of perception by, say, 1985, it would have been for the legislature, and not for the courts, to decide whether, and if so to what extent, to criminalise price-fixing. ${ }^{59}$

The decision in Norris raises a serious contention in relation to the criminal cartel offence: did price fixing in itself become dishonest with the passing of the Enterprise Act 2002, or must it still be accompanied by some 'aggravating features' other than secrecy ${ }^{60}$ It is hoped that the Lords' reading of dishonesty is treated as contextually distinct; applying only to conspiracy to defraud, and cartel conduct preceding the 2002 Act. However, there is still a question as to whether price fixing has in itself become objectively dishonest 'according to the ordinary standards of reasonable and honest people' now that the statutory cartel offence has been created. A public survey gives us some indication of contemporary attitudes.

\subsection{Convincing the Jury of Dishonesty}

Britain's historical tolerance of cartels is not unique; in Germany cartel membership was once compulsory in some industries. ${ }^{61}$ In times of great economic instability, collusive practices have been viewed by policy makers in numerous jurisdictions as important mechanisms for keeping prices stable or for protecting domestic industries; indeed, export cartels are still exempted by most competition law regimes. The Competition Act 1998 and Enterprise Act 2002 marked a remarkable hardening of UK laws regulating cartels. They introduced far reaching investigatory powers, corporate fines of up to ten per cent of an undertaking's annual turnover, and up to five years imprisonment of culpable individuals. The question is the extent to which the corresponding public perceptions of price fixing have also hardened. Apart from the issue of objective

\footnotetext{
${ }^{59}$ They also pointed out that criminalisation by a change in public perception would be hard to reconcile with the Strasbourg Court's decision Hashman and Harrup v United Kingdom (1999) 30 EHRR 241 in which it stated that courts could not characterise an act as criminal simply because it was considered wrong by the 'majority of contemporary fellow citizens' (at 38)

$60 \mathrm{~J}$ Joshua, 'Norris: A stalking horse for the cartel offence?' (2008) Competition Law Insight 72 (11)

${ }^{61}$ See C Harding and J Joshua, Regulating Cartels in Europe: A Study of Legal Control of Corporate Delinquency (Oxford: OUP, 2003) at Chapter 3. See also: A. Stephan, 'Beyond the cartel law handbook: how corruption, social norms and collectivist business cultures can undermine conventional enforcement tools' (2008) unpublished paper. CCP Working Paper 08-29 available at: http://www.ccp.uea.ac.uk/publicfiles/workingpapers/CCP08-29.pdf accessed 20 Oct 2008
} 
dishonesty, a failure to acknowledge the severity of cartel offences would affect the criminal offence's perceived legitimacy and proportionality. ${ }^{62}$ Hardened attitudes can also strengthen normative compliance as a complement to instrumental deterrence (desistance resulting from fear of consequences), by encouraging businessmen not to collude and focusing attention to the hazards of such conduct. ${ }^{63}$

In March 2007 the ESRC Centre for Competition Policy commissioned a survey gauging public attitudes in Britain towards price fixing and cartel enforcement. ${ }^{64}$ This was the first survey of its kind and was carried out online by YouGov Plc. ${ }^{65}$ A representative sample of 1,219 residents of Great Britain (aged 18 or over) was surveyed; a response rate of 41 per cent. ${ }^{66}$ Importantly, respondents demonstrated a good understanding that when competitors agree on what price to charge, they will raise prices so as to maximise their collective profits to the detriment of their customers. Nearly three quarters of respondents (73 per cent) recognised that price fixing is harmful, and believed it should be punished. All respondents were asked whether they felt price fixing was dishonest:

Table 1: Survey Responses: Extent to Which Price Fixing is Dishonest

\begin{tabular}{|l|l|}
\hline & $\%$ \\
\hline Dishonest (of which strongly) & $\mathbf{6 3 ( 2 5 )}$ \\
\hline Not Dishonest (of which strongly) & $\mathbf{2 1 ( 2 )}$ \\
\hline Neither & 11 \\
\hline Don't know & 5 \\
\hline
\end{tabular}

Whereas six in every ten respondents believed price fixing was dishonest and two in every ten believed it was not, only a quarter of respondents strongly felt

\footnotetext{
${ }^{62}$ Von Hirsch et al., above $\mathrm{n} 6$ at 40

63 Ibid. at 3

${ }^{64}$ The survey questions were designed by this author with the assistance of colleagues within CCP. They were piloted at the BA Festival of Science at the University of East Anglia in September 2006, then developed further over a period of six months

${ }^{65}$ YouGov maintain a panel of 160,000 adults throughout Great Britain. Responses are weighted to ensure they are representative of key demographic characteristics. For a detailed discussion of YouGov's methodology, see A Stephan, 'Survey of Public Attitudes to Price-Fixing and Cartel Enforcement in Britain' (2008) forthcoming. Competition Law Review and www.yougov.com 20 Oct 2008. For a comparison of YouGov accuracy in the 2005 General Election, as compared to face-to-face interviews, see D Sanders et al., 'Does Mode Matter for Modelling Political Choice? Evidence From the 2005 British Election Study'(2007) Political Analysis 15 (Autumn).

${ }^{66}$ As a guide: for a 1,000 sample, margin of error is in the region of $+/-3$ percentage points based on a 95\% confidence interval (YouGov)
} 
price fixing was dishonest. In a separate question, only 11 per cent of respondents who felt price fixing was harmful believed imprisonment was an appropriate punishment. These figures are lower than one would expect, given that the overwhelming majority of Britons do recognise that price fixing is harmful. They suggest that public opinion may not yet have caught up with criminalisation.

One would hope that a prosecutor is easily able to remedy this by convincing a jury of the seriousness of cartel conduct, in particular by pointing out its harmful effects. However, convincing a jury (and the public) that secret price fixing is in itself dishonest is not without obstacles, not least given the historical factors and reasoning outlined in Norris. A major difficulty is identifying victims and quantifying harm. Cartels typically operate in upstream markets, where overcharges are passed on to final consumers and thus dispersed between a large number of actors who may not even be aware that they suffered a loss. Demonstrating the extent of harm or loss is a very difficult exercise because it requires an accurate assessment of how prices would have changed had the cartel not existed; competition authorities typically do not attempt to measure the overcharge when calculating fines for example, at least not with any real accuracy. Stucke notes how difficult early US antitrust prosecutors found securing criminal sanctions for conduct that juries viewed as 'so abstract, so little tainted with a general and customary imputation of immorality.... ${ }^{67}$ The use of immunity as a principle cartel enforcement tool may also pose an obstacle. Detection rates would be substantially lower in the absence of leniency programmes, yet their use becomes increasingly unsavoury as cartel sanctions are stepped up. For example, in August 2007 British Airways incurred fines of $£ 121.5$ million and $\$ 300$ million ( $£ 148 \mathrm{~m}$ ) in the UK and US for the fixing of fuel surcharges in cross-Atlantic flights. BA's co-conspirators, Virgin Atlantic, received immunity in both jurisdictions for revealing the agreement. Lay observers expressed some bemusement at Virgin escaping punishment altogether and criticised Richard Branson for not being forthcoming with an

\footnotetext{
${ }^{67}$ M E Stucke, 'Morality and Antitrust' (2006) Columbia Business Law Review 2006:443 at 461 quoting: A A Young, 'The Sherman Act \& the New Anti-trust Legislation' (1915) 23 Political Economy 201, at 218
} 
apology. ${ }^{68}$ Moreover, the OFT found itself having to defend its leniency programme in the press. ${ }^{69}$

A final obstacle is that any anticompetitive act can have some pro-competitive effects. In fact, many economists such as Posner advocate an effects-based approach to even hard core cartels, rather than a per se ban. ${ }^{70}$ Moreover, others argue that if an attempted cartel is immoral, then a criminal offence should surely extend to attempted anticompetitive mergers and the abuse of dominance. ${ }^{71}$ Any breach of Article 81 (or Chapter I, Competition Act 1998) is capable of being excepted by efficiency arguments under Article 81(3). ${ }^{72}$ The European Commission's guidelines state that such exemptions are extremely unlikely in 'object' agreements such as explicit price fixing. Yet in REIMS /I an agreement between European postal operators to fix the fees for cross-border deliveries was excepted because of the industry's 'unusual characteristics'. ${ }^{73}$ The UK offence only applies to hardcore horizontal cartel practices and it was thought that a standard of dishonesty would limit the scope for an efficiency defence. ${ }^{74}$ English courts would in any case struggle with the complex economic arguments an efficiency defence typically entails, and in balancing the pro- and anti-competitive effects of an agreement. Nevertheless, efficiency arguments may still be relied upon in denial of dishonesty, but these will be less convincing where extensive efforts have been made to hide an agreement from customers. $^{75}$

The importance and difficulty of hardening public attitudes to cartels was acknowledged when the cartel offence was being drafted. The inclusion of dishonesty was thought to signal the seriousness of practices such as price fixing. This was expressed in the Penrose Report and by Patricia Hewitt (then Secretary of State for Trade and Industry) who announced that, 'the new

\footnotetext{
${ }^{68}$ For example, R Peston, 'Where's Branson's Apology' BBC News, Comments Post at http://www.bbc.co.uk/blogs/thereporters/robertpeston/2007/08/wheres bransons apology.html accessed 20 Oct 2008

${ }^{69}$ For example, R Sunderland, 'OFT defends 'snitch' policy' The Observer, London. August 5, 2007

${ }^{70}$ Posner, above n 6 at Chapter 3

${ }^{71}$ Stucke, above $\mathrm{n} 67$ at $527-528$

72 'Guidelines on the application of Article 81(3) of the Treaty' [2004] OJ C 101, at 46

73 1999/687 (1999) OJ L275/17 at 69

${ }^{74}$ Penrose Report, above n 19 at 2.5-2.6; White Paper, above n 2

${ }^{75}$ White Paper, above $\mathrm{n} 2$ at 8
} 
criminal offence will send out a strong message to the perpetrators, their colleagues in business, the general public and the courts'. ${ }^{76}$ This perhaps also confirms the observation in Norris that there was no evidence of a shift in public perceptions of cartels prior to the Enterprise Act 2002. However, the public survey may suggest that the criminal offence has thus far failed to sufficiently harden attitudes, especially in the absence of regular convictions. If the lack of prosecutions are due to doubts over whether a jury will consider price fixing to be in itself dishonest, then criminal cartel enforcement in the UK may be in a quagmire. The requirement of dishonesty may be incapable of increasing the 'moral offensiveness' of cartel practices while it hinges on a contemporary objective judgement. ${ }^{77}$ The lack of prosecutions means that the UK cartel offence can only have a very limited deterrent effect, especially as the first convictions were induced by US enforcement. By contrast, the DOJ secured the criminal conviction of 19 individuals in the fiscal year ending 30 September 2006 alone. In that year, fines on individuals totalled $\$ 473$ million and prison sentences were imposed totalling over five years. ${ }^{78}$

The UK is unique in employing a cartel offence hinging on dishonesty. In Australia, a cartel offence requiring dishonesty was proposed under the Exposure Draft Bill (January 2008), but is very unlikely to be adopted by the legislature following serious criticism by competition law academics and practitioners. ${ }^{79}$ Possible alternatives to Ghosh dishonesty are discussed in detail by Fisse. These include: retaining a re-defined dishonesty test that is not reliant on the notion of 'ordinary standards'; adopting a test of recklessness in relation to all physical elements of the offence; and adopting a test of conspiracy, or common intention. Fisse goes on to forward specific proposals for an offence of 'conspiracy to subvert competition' without a dishonesty element. ${ }^{80}$ Whereas the UK offence applies only to individuals, it is more

\footnotetext{
${ }^{76}$ Penrose Report, above n 19 at 2.5-2.6; HC Deb col 47 (10 April 2002), at 4; Lever and Pike, above n 34 at $166-167$

$77 \mathrm{~J}$ Joshua and C Harding, 'Breaking up the hard core: The prospects for the proposed cartel offence' (2002) Crim L R 933, at 938; MacCulloch, above n 23 generally

78 GF Masoudi, 'Cartel Enforcement in the United States (and Beyond)' (Speech delivered at The Cartel Conference, Budapest. February 2007) http://www.usdoj.gov/atr/public/speeches/221868.htm 20 Oct 2008

${ }^{79}$ For examples, see: Fisse, above $n$ 24; and Caron Beaton-Wells, 'The politics of cartel criminalisation: a pessimistic view from Australia' (2008) ECLR 29(3) 185-195. Both have cited the public survey discussed in this paper

${ }^{80}$ See Fisse, above n 24 at $266-277$
} 
common for criminal cartel offences to extend to undertakings too, with a parallel administrative procedure available for less serious infringements. ${ }^{81}$ In Ireland, under the Competition Act 2002, s.8(7):

[Where the offence has been committed by an undertaking] and it is proved that, at the material time, he or she was a director of the undertaking concerned or a person employed by it whose duties included making decisions that, to a significant extent, could have affected the management of the undertaking, or a person purported to act in such a capacity, it shall be presumed, until the contrary is proved, that that person consented to the doing of the acts by the undertaking which constituted the commission by it of the offence concerned...

Where a criminal infringement by a firm is established, there is thus a presumption that the relevant directors and/or managers have consented to anticompetitive behaviour unless they can prove the contrary. The standard of proof for this presumption to be overturned is balance of probabilities, as per s.3(3)(a). An ignorance defence originally contained in s.2(2)(c) of the 1996 Act was removed by the 2002 Act. ${ }^{82}$ The Irish criminal offence yielded no successful prosecutions before the 2002 Act; in part due to inadequate resources and limited investigatory powers. ${ }^{83}$

In the US, where the alleged behaviour (such as price fixing) is per se illegal under s.1 Sherman Act, the prosecutor 'need only prove the existence of an agreement and that the defendant knowingly entered into the alleged agreement or conspiracy'. Conduct that is not per se illegal can also attract criminality where it is known that anticompetitive effects would more than likely follow. ${ }^{84}$ However, the effects of different cartel enforcement tools are complex and interrelated. In order to understand why criminal convictions are so common in the US, cartel enforcement must be considered as a whole. In this respect, certainty is central to the US success and is enhanced by the availability of coordinated leniency for corporations and individuals, and the use of plea bargains.

\footnotetext{
${ }^{81}$ This was discussed as an option in the UK White Paper, but was dropped in favour of an independent offence based on dishonesty; S Parkinson, 'The Cartel Offence Under the Enterprise Act 2002' (2004) Company Lawyer 25(6), at 187-189

82 Joshua and Harding, above n 77 at 939

${ }^{83}$ Massey, above $\mathrm{n} 15$ at $27-28$

${ }^{84}$ Stucke, above $n 67$ at 492-493; United States v US Gypsum Co., 438 US 422, 444-446 (1978); Sheryl A. Brown \& Christopher Kim, 'Antitrust Violations' (2006) 43 American Criminal Law Review 217, at 227
} 


\section{Certainty in Cooperation}

As cartels are secretive agreements which may be formed in any of a large number of industries, leniency programmes are the principle detection tool. The offer of immunity to the first firm that self-reports has succeeded in uncovering three quarters of the infringements fined by the European Commission since its introduction in July 1996. ${ }^{85}$ The majority had been previously or contemporaneously uncovered in the US where leniency also plays a central role. According to the DOJ (the pioneers of leniency in cartel enforcement) certainty is a key cornerstone of a successful leniency programme. ${ }^{86}$ Firms are only likely to self-report if they have a reliable understanding of how they will be treated once they step forward. In Europe, this consideration was central to the reforms undertaken to the leniency notice in 2002 and $2006 .^{87}$ The use of criminal sanctions as a complement to corporate fines should increase the effectiveness of leniency programmes, as the offer of immunity becomes more tempting. In the US, certainty is maintained by automatically extending immunity to the directors, officers and employees of the revealing firm. ${ }^{88}$ In Europe, the situation is more complicated. The most serious cartel infringements (those affecting more than one member state) are dealt with by D-G Competition in a civil procedure. Thus far, the number of criminal prosecutions within Member States has been negligible and so there has not been a problem, but if prosecutions are to be stepped up some may be discouraged from coming forward; the Commission's leniency notice does not - and cannot - guarantee against criminal prosecutions on the member state level.

Consequently, the individuals within a firm responsible for a cartel may be discouraged from self-reporting to the Commission, as they will also have to apply for a no-action letter from the OFT and any other jurisdiction with a

\footnotetext{
${ }^{85}$ A Stephan, 'An Empirical Assessment of the European Leniency Notice' (2008) forthcoming. Journal of Competition Law and Economics

${ }^{86}$ SD Hammond, 'Cornerstones of an Effective Leniency Program' (Speech delivered to ICN Workshop on Leniency Programs, Sydney. November 2004) http://www.usdoj.gov/atr/public/speeches/206611.htm accessed 20 Oct 2008

87 See generally: Stephan, above $\mathrm{n} 85$

${ }^{88}$ US Department of Justice (Antitrust Division), 'Corporate Leniency Policy' http://www.usdoj.gov/atr/public/guidelines/0091.htm accessed 20 Oct 2008
} 
criminal offence. ${ }^{89}$ No-action letters should be granted as a matter of routine where a firm has qualified for immunity from civil fines within the UK (domestic infringements). ${ }^{90}$ However, no-action letters can in themselves lack certainty. First, the OFT cannot guarantee against prosecution in Scotland; cooperation by an individual is reported to the Lord Advocate who will take it into account. ${ }^{91}$ Secondly, individuals will not know whether they have been beaten to the immunity prize until they have come forward. Unlike leniency programmes in the UK and EU, where substantial fine discounts are available once immunity has been claimed, the runner up for a no-action letter receives no protection. Moreover, even where a no-action letter has not been previously issued, the OFT still reserves the right to turn an application down:

...the fact that [the conditions for the issue of a no-action letter] are satisfied in any particular case is not in itself sufficient for the issue of a noaction letter. Where the OFT believes that it already has, or is in the course of gathering, sufficient information to bring a successful prosecution of an individual, it will not issue a no-action letter to that individual. ${ }^{92}$

There have already been moves within the EU towards the harmonisation of corporate leniency and a one-stop shop for applicants. Similar arrangements will one day also be necessary for immunity from criminal prosecution; in particular the employees of a firm that is granted immunity from fines by D-G Competition should be given priority for no-action letters or equivalent from competition prosecutors within Member States.

Infringing firms and their employees in the US have the added certainty of a speedy resolution to both their liabilities through a plea bargain, should immunity no longer be available. Informal settlements in one form or another are available in the UK; indeed the OFT has used its discretion under the Competition Act 1998 to reach a form of direct settlement in the Sevenoaks Survey case and 'Early Resolution Agreements' in cases concerning the price

\footnotetext{
${ }^{89}$ S.190(4) Enterprise Act; OFT, 'Guidance on the issue of no-action letters for individuals' (2003) OFT513

90 OFT, 'Leniency and no-action: Guidance on the issue of no-action letters for individuals' (2003) OFT513

91 Ibid. at 3.2

92 Ibid. at 3.4
} 
fixing of dairy and tobacco products. ${ }^{93}$ However, these are not as conclusive as US plea bargains which allow parties to have some power to negotiate the fine or prison sentence they will face (within the limits of Federal guidelines). Plea bargains are binding agreements which limit the amount of information about the infringement that becomes public (a particular attraction in the US where private antitrust claimants can sue for treble damages) and which require defendants to waive their right to appeal. ${ }^{94}$ They also provide a procedure through which corporate and individual liabilities can be settled contemporaneously. A common feature of plea bargains is also a recommendation to the Bureau of Prisons that they assign the defendant to a minimum security prison or 'camp'. Defendants can even request a specific prison so as to be closer to their families. ${ }^{95}$ There are substantial differences in standards between US prisons. Among those most commonly requested in the past by cartelists are: Ashland (Kentucky) and Lompoc (California) which include amenities such as a 'wellness' programme and a 'full gym and tennis courts'. ${ }^{96}$ Referred to as 'Club Feds' by more cynical observers however, these prisons may blunt the deterrent effect of incarceration.

It is estimated that some 90 per cent of defendants in US antitrust cases enter into plea bargains. ${ }^{97}$ The attraction of plea bargains is demonstrated by the fact that they have facilitated the voluntary surrender of foreign defendants who have re-entered the US to serve an agreed jail sentence. ${ }^{98}$ It was also a plea

\footnotetext{
93 OFT Press Release, 'OFT welcomes early resolution agreements and agrees over $£ 116 \mathrm{~m}$ penalties' Press Release, (07 December 2007); see also 'OFT reaches early resolution agreements in tobacco case' (11 July 2008)

${ }^{94}$ For a review of the advantages and costs of negotiated settlements, see: A Stephan, 'The Direct Settlement of EC Cartel Cases' DG Competition - Public Consultation on Cartel Settlements (January 2008) http://ec.europa.eu/comm/competition/cartels/legislation/cartels settlements/astephan.pdf accessed 20 Oct 2008

${ }_{95}^{95}$ Examples include: USA v Young Hwan Park (14 Feb 2007); USA v Thomas Quinn (8 Nov 2006); USA v Wolfgang Kock (24 Jun 2005); USA v T.Rudd Corwin (15 Dec 2004). Plea agreements available: http://www.usdoj.gov/atr/cases.html\#k accessed 20 Oct 2008

96 'Best Places to go to Prison', Forbes.com 25 May 2006 at: http://www.forbes.com/2006/04/17/best-prisons-federal cx Ir 06slate 0418bestprisons.html accessed 20 Oct 2008; a US defence lawyer specialising in white collar crime has written a guide book to the best US prisons: A Ellis, Federal Prison Guidebook (Law Offices of Alan Ellis, Pennsylvania 2005)

97 SD Hammond, 'The US Model of Negotiated Plea Agreements: A Good Deal With Benefits For All' (Speech delivered to OECD Competition Committee Working Party No. 3, Paris. October 2006) http://www.usdoj.gov/atr/public/speeches/219332.htm accessed 20 Oct 2008

98 SD Hammond, 'When Calculating The Costs and Benefits of Applying For Corporate Amnesty, How Do You Put A Price Tag On An Individual's Freedom?' (Speech delivered to Fifteenth Annual National Institute on White Collar Crime, San Francisco. March 2001) http://www.usdoj.gov/atr/public/speeches/7647.htm accessed 20 Oct 2008
} 
bargain which resulted in the first three convictions under the UK offence. The individuals were arrested in Houston and agreed to return to the UK on the condition that they would plead guilty to the UK offence and return to the US if their UK sentence was less than 20-30 months. The defence lawyers thus found themselves in a precarious position when making arguments in mitigation and the UK sentences were longer than those agreed in the US. ${ }^{99}$ The only other individuals charged under the UK offence at time of writing were four employees of British Airways in connection with the price fixing of fuel surcharges in long haul passenger flights. These individuals are likely to plead guilty to the UK offence in order to avoid extradition to the US, where the potential penalty is now ten years in prison if they refuse to enter a plea bargain. ${ }^{100}$ One BA executive (Keith Paker) is already serving a jail term in the US for price fixing in air cargo fuel surcharges; a criminal investigation into that aspect of the infringement was not launched by the OFT. ${ }^{101}$ Appendix 1 lists 43 US and foreign individuals imprisoned for international cartel offences under the Sherman Act, including their sentence, whether a plea bargain was reached, the cartel, employer, position held and nationality.

Plea bargains allow the DOJ to secure a regular number of convictions every year by circumventing a criminal trial and subsequent appeals in most cases. This in turn frees up resources with which to tackle more cartel infringements. It is not the contention of this writer that US-style plea bargains can or should be adopted for settling all cartel cases within the UK. For one thing it has taken decades of case law and practice to forge the enforcement system which exists in the US today and plea bargains are certainly not without criticism for being unfair and inconsistent. ${ }^{102}$ Moreover, the formal characteristics of US plea bargains reflect American peculiarities in '[legal] culture, institutional practice, attitude to corporate crime and the role of the market'. ${ }^{103}$ However the success

\footnotetext{
99 OFT Press Releases, above n 3; S D Hammond, above n 3

100 See D Milmo 'British Airways executives charged over price fixing scandal' The Guardian, London. 7 Aug 2008; E Fennell 'Vichyssoise or gazpacho, sir?' The Times, London. 17 Oct 2006; 'BA cartel probe sees OFT test its criminal powers post-Enterprise Act' (2006) The Lawyer, 06 November

${ }^{101}$ DOJ Press Release, above $\mathrm{n} 4$

102 Joshua and Harding, above n 77 at 935; See generally: WPJ Wils, 'The Use of Settlements in Public Antitrust Enforcement: Objectives and Principles' (2008) World Competition 31, no 3: 335-352

${ }^{103}$ PK Gorecki and D McFadden, 'Criminal Cartels in Ireland: the Heating Oil Case' (2006) ECLR 27(11), $631-640$ at FN8
} 
of completing US criminal cases has been driven to a large extent by plea bargains and it may be that the number of UK cases will remain sparse in the absence of such a conclusive mechanism of direct settlement.

\section{Prison and What Comes After}

The potential gains from practices such as price fixing can be enormous, making it difficult to ensure an effective level of deterrence is achieved. This is compounded by a general consensus that the likelihood of cartel detection is substantially low, and a 1998 British Crime Survey study which suggests that members of the public tend to substantially underestimate the general severity of sanctions imposed. ${ }^{104}$ The prospect of imprisonment in cartel cases may provide a particular deterrent effect for company executives because of their relative affluence and preconceptions about the experience of incarceration and the social stigma attached to it. In this respect, imprisonment may attract a stronger social stigma than the cartel offence itself. Moreover, although it was noted earlier in this paper that certainty of punishment has been shown to be more important to deterrence than severity, the two may be viewed as inextricably linked in cartel enforcement, where the primary detection tool is the offer of immunity to the first party to self-report. The offer becomes more inducing, the greater the potential punishments awaiting those beaten to the immunity prize. This change in the consequences faced by cartelists may be strong enough to convince them to either change their behaviour or report more infringements, particularly relative to the gains from the offence. ${ }^{105}$ It is thus helpful to consider what happens after a conviction is secured, drawing on the experiences of other jurisdictions. It may be that further mechanisms are needed to ensure imprisonment has a deterrent effect.

Although the circumstances of the first UK convictions were unusual (in particular the terms of the defendants' US plea bargain), it is very encouraging

\footnotetext{
${ }^{104}$ See OECD 'Fighting Hard Core Cartels: Harm, Effective Sanctions and Leniency Programmes' (2002) Reports to the Organization for Economic Co-Operation \& Development; Wils, above n 6 at 6.5.2.2; Bryant and Eckard, above $\mathrm{n} 7$ at 531; M Hough and J Roberts, Attitudes to Punishment: Findings from the British Crime Survey, Home Office Research Study No.179 (London: HMSO, 1998)

${ }^{105}$ For a discussion of consequences and gains in deterrence see: Von Hirsch et al., above n 6 at 6
} 
that substantial custodial sentences were imposed. All UK prosecutions pursuant to international cartel infringements are likely to occur under the shadow of US antitrust enforcement and the threat of extradition. This should encourage guilty pleas, especially as there has been an escalation of enforcement in the US in recent years. The Antitrust Criminal Penalty Enhancement and Reform Act 2004 increased the maximum sentences for Sherman Act offences from three to ten years. Average jail sentences have increased significantly since the 1990s, averaging 31 months for US citizens and 12 months for foreign nationals in 2007. The percentage of defendants sentenced to jail has also increased from 37 per cent in the 1990s to 87 per cent in 2007. ${ }^{106}$ However it is unclear whether custodial sentences will be imposed in the majority of UK cases, particularly in relation to domestic infringements. These may be viewed as more important to hardening attitudes as they tend to involve sales to final consumers, rather than obscure upstream products such as graphite electrodes or lysine. It is notable that the Republic of Ireland has only thus far prosecuted domestic criminal cases and these have all resulted in suspended sentences. The first criminal conviction in 2006 concerned heating oil in County Galway. ${ }^{107}$ The second in 2007 concerned the selling price of Ford Cars in Ireland. ${ }^{108}$ Substantial personal fines were imposed in the two cases, as well as two custodial sentences of 6 and 12 months respectively. ${ }^{109}$ However both these sentences were suspended. In the Heating Oil Case, the sentence of 69 year old J.P. Lambe was mitigated by claims that the stress of the trial had exacerbated a heart condition, and by character references from his parish priest, and others describing him as 'honourable, trustworthy and reliable'. 'Judge Delahunt said Lambe was a devoted and dedicated family man who came before the court with an unblemished record

\footnotetext{
${ }^{106}$ See Hammond, above $\mathrm{n} 3$ generally

107 The Director for Public Prosecutions v Michael Flanagan, Con Muldoon, Muldoon Oil, James Kearney, All Star Oil, Kevin Hester, Corrib Oil, Mor Oil, Alan Kearney, Sweeney Oil, Gort Oil, Pat Hegarty, Cloonan Oil, Ruby Oil, Matt Geraghty Oil, Declan Geraghty, Fenmac Oil \& Transport, Michael McMahon, Tom Connolly, Eugene Dalton Snr., JP Lambe, Sean Hester, Hi-Way Oil, Kevin Cunniffe. unpublished. See Irish Competition Authority Website at http://www.tca.ie/templates/index.aspx?pageid=856 accessed 20 Oct 2008

${ }^{108}$ The Director for Public Prosecutions v Denis Manning, 19 April 2006. unpublished. See Irish Competition Authority Website at http://www.tca.ie/templates/index.aspx?pageid=856 accessed 20 Oct 2008

${ }^{109} € 90,000$ in the Heating Oil Case, with 15 convictions: 14 guilty pleas and 1 conviction by Jury by late 2006; See Gorecki and McFadden, above n 103 at 632
} 
until becoming involved with the cartel'. ${ }^{110}$ Sixty-eight year old D. Manning's sentence in the Ford case was also suspended because of his age. ${ }^{111}$ Most recently, 62 year old James Durrigan and 58 year old Jack Doran received three month suspended sentences in May and October 2008 for the price fixing of Citroen cars between 1997 and 2002. ${ }^{112}$

Under s.189 Criminal Justice Act 2003, sentences of imprisonment in England and Wales of between 28 and 51 weeks can be suspended for between six months and two years. ${ }^{113}$ The Sentencing Council's Seriousness Guidelines state that prison should be reserved for where a fine or a community sentence cannot reflect the severity of an offence; a decision that is left at the judge's discretion. The sentencing guidelines also emphasise the importance of preventing re-offending, and state that 'custody can still be avoided in the light of personal mitigation'. ${ }^{114}$ The pressure to reserve prison for individuals who pose the greatest threat of re-offending - in particular violent offenders - is heightened by concerns over prison overcrowding and political pressure on the judiciary to more extensively employ alternatives to custody. ${ }^{115} \mathrm{~A}$ consultation paper on sentencing in fraud cases in England and Wales notes falling rates of custodial sentences in favour of community orders. ${ }^{116}$ Moreover in $R \vee$ Kefford the Court of Appeal expressed the view that where there is no record of previous offences in 'economic crimes', a mere court appearance 'can be a significant punishment', and 'having to perform a form of community punishment can be a very salutary way of making it clear that crime does not pay.... ${ }^{117}$ The introduction of sentencing guidelines specifically for theft and fraud is unlikely to reverse this trend. ${ }^{118}$

\footnotetext{
110 ‘ $€ 4.4 \mathrm{~m}$ fuel price-fixer gets a €15,000 fine' The Irish Independent, Dublin. 07 Mar 2006

111 'Sentence suspended in price fixing case' RTÉ, Dublin 9 Feb 2007

112 'Suspended sentence and fine for fixing prices of Citroen cars' Irish Times, Dublin. 29 Oct 2008; 'Car dealer avoids jail in price-fix court case' The Irish Independent, Dublin 9 May 2008

113 at 2.2.7, Sentencing Guidelines Council, 'New Sentences: Criminal Justice Act 2003' (December 2004)

114 Sentencing Guidelines Council, 'Overarching Principles: Seriousness' (December 2004) at 1.31-1.33

115 'Ministry to tackle crowded prisons' BBC News, London 9 May 2007

${ }^{116}$ Sentencing Guidelines Council, 'Consultation paper on sentencing for fraud offences' (16 August 2007) at Tables 2-4

117 [2002] 2 Cr App R (S) 106

118 Sentencing Guidelines Council, 'Consultation paper on sentencing for fraud offences' (16 August 2007) and 'Consultation paper on theft and dishonesty' (1 Nov 2006)
} 
Under s.166(1) Criminal Justice Act 2002, a sentencer may take into account any factors that 'in the opinion of the court, are relevant in mitigation of the sentence'. The typical cartelist fairs rather well in arguing mitigating circumstances. They tend to be later in life and have health problems; sixty-five year old lan Norris suffered from prostate cancer, for example. In many cases old age will be exacerbated by the duration of a cartel, plus the lengthy investigation and trial process. Cartelists are also unlikely to have criminal records or to re-offend, and many come with glowing character references as otherwise upstanding members of society. For example, at the US trial of Alfred Taubman references were read from prominent figures including former US president Gerald Ford, former Secretary of State Henry Kissinger, and Queen Noor of Jordan. ${ }^{119}$ Where price fixing has occurred at the top level of a firm, it is not uncommon for defendants to have strong political links too. The influence the Andreas family flexed in Washington during the Lysine cartel trials is well documented in Eichenwald's book The Informant. ${ }^{120}$ A more recent example is the very public statements made in 2007 by the then Australian Prime Minister, John Howard, in support of Richard Pratt. The prominent Australian businessman admitted that he allowed price fixing to occur between his packaging company Visy and rival Amcor. ${ }^{121}$ The PM's public statements included 'I have always found Mr Pratt in my own personal dealings with him to be a very good citizen'. Australia was in the process of adopting a criminal offence at the time, and the Pratt episode coincided with weakened enthusiasm for criminalisation within the Howard government. ${ }^{122}$

What comes after prison can be as important to deterrence as the threat of incarceration itself. Negin points out that the pains of threatened punishment may depend to a considerable extent on their potential stigmatising effects -

\footnotetext{
119 'Sotheby's chief gets year in jail' BBC News, London 23 April 2002

${ }^{120} \mathrm{~K}$ Eichenwald, The Informant (Broadway, New York 2000)

${ }^{121} \mathrm{P}$ Ryan, 'Visy boss admits to price fixing' ABC News, Sydney 9 October 2007

122 'Treasurer noncommittal on Trade Practices Act sanctions' ABC News, Sydney 9 October 2007; however, there is some evidence of hardening attitudes to sentencing in white-collar crimes among members of the Australian Judiciary. See comments by Justice Finkelstein in: ACCC v ABB Transmission and Distribution Ltd [2002] FCA 559 at 28. With reference to D Baker and R Reeves, 'The Paper Label Sentences: Critiques' (1977) 86 Yale L J 619, 622, he suggested the need to focus on the 'character of the offence' rather than of the defendant. He did however go on to reject optimal deterrence theory (at 19-25)
} 
especially within social groups. ${ }^{123}$ In particular, we would thus hope that industry demonstrates some resistance to employing former cartelists upon their release from prison. A study in the 1970s found that corporate executives convicted of white-collar crime in the US had little difficulty finding similar employment after their release. ${ }^{124}$ One would expect firms to be less hostile to price fixing criminals than to conventional white-collar criminals such as fraudsters. Whereas the latter is likely to have stolen from their employer (or the firm's shareholders), the former may have acted in his employer's best interest, certainly in the short run, but also in the long run where a crisis cartel was formed. Looking at the imprisoned individuals listed in Appendix 1, anecdotal evidence suggests that many of those who did not retire following release had little trouble seeking re-employment at the top level. Mark Whitacre, the famous embezzler-turned-whistleblower of ADM, is now the Chief Operating Officer and President of Technology and Business Development for Cypress Systems Inc. ${ }^{125}$ Kuno Sommer, formerly of F. Hoffmann-La Roche Ltd, is now Vice Chair of the Board of Pevion Biotech Ltd. ${ }^{126}$ Bjorn Sjaastad, formerly of Odfjell Seachem, became CEO of Frontline Management A.S. within the shipping tanker firm Frontling Ltd. ${ }^{127}$ Erik Anders Broström did not even lose his job at Akzo Nobel despite spending three months in prison. The decision not to fire him was apparently made because he gave full cooperation to the authorities. $^{128}$

A recurring characteristic of many of these cartelists is their value as human capital, including high levels of education and experience. Roland Brönnimann, (formerly of F. Hoffmann-La Roche Ltd) was appointed as President and CEO of Synthes Ltd's European and Latin American Operations in 2000, soon after

\footnotetext{
${ }^{123}$ DS Nagin, 'Criminal Deterrence Research at the Outset of the Twenty-First Century' (1998) Crime and Justice: A Review of Research 23:51-91

${ }^{124}$ MB Clinard and PC Yeager, Corporate Crime (The Free Press, New York 1980) at 272; E Szockyj, 'Imprisoning White-Collar Criminals?' (1999) 23 Southern Illinois University Law Journal Winter 485, 497 EN 21

${ }_{125}^{125}$ See Cypress Systems website at http://www.cypsystems.com/production.html accessed 20 Oct 2008

${ }^{126}$ See the company's website at http://www.pevion.com/index.php?page=696 accessed 20 Oct 2008

${ }_{128}^{127}$ See profile at Forbes.com: http://people.forbes.com/profile/bjorn-sjaastad/47622 accessed 20 Oct 2008

128 'Akzo Nobel Employee is Jailed for Price Fixing' ICIS News 2 July 2001 at http://www.icis.com/Articles/2001/07/02/141988/akzo-nobel-employee-is-jailed-for-price-fixing.html accessed 20 Oct 2008
} 
he had completed his jail sentence. In a press release, the corporation's Chairman and CEO stated that:

While with Hoffmann-La Roche, Dr. Brönnimann was found to be involved in matters concerning pricing which took place in the vitamin industry during the 1990s. He accepted his responsibility for his involvement, along with others, and the matter is now in the past. I am very pleased that Dr. Brönnimann, an expert with international experience, is joining Synthes-Stratec, and will assist us in strengthening our management team. ${ }^{129}$

Clearly any stigma attached to Brönnimann's actions while at La Roche was overshadowed by his expertise and experience.

Thanks to s.204 Enterprise Act 2002 (which amended the Company Directors Disqualification Act 1986), company directors can now be disqualified and prevented from holding office for a period of up to 15 years where they knew or ought to have known that their company was guilty of an infringement of EC or UK competition law. It can be invoked where it is likely that an investigation into a company director's firm will result in a fine being imposed. ${ }^{130}$ However, a Competition Disqualification Order (CDO) can only be imposed against a director of a company, not against other senior management. ${ }^{131}$ Moreover, although a CDO prevents an individual from 'in any way, whether directly or indirectly, be[ing] concerned or tak[ing] part in the promotion, formation or management of a company', in practice this may be difficult to enforce. ${ }^{132}$ One possibility is to impose an income cap for a given period, which could be enforced through the Inland Revenue.

\section{Concluding Remarks}

The UK Cartel offence was introduced by the Enterprise Act 2002 primarily to enhance deterrence. As well as ensuring that the consequences of businessmen's collusive acts are not borne solely by the corporation and its

\footnotetext{
${ }^{129}$ Press Release, May 2000 http://www.synthes.com/html/Mai-5-2000-Synthes-Stratec.4479.0.html accessed 20 Oct 2008

${ }_{130}$ OFT, 'Competition disqualification orders'. (2003) OFT510 at 4.10

131 Ibid. at 2.3

132 Ibid. at 2.10
} 
shareholders, criminalisation ostensibly plugs any shortfall in deterrence caused by undertakings' limited ability to pay administrative fines. In order for an offence to exist, a jury must find that a defendant acted 'dishonestly' according to the standards of 'reasonable and honest people', and must have realised that they were acting dishonestly by those standards ( $R \vee$ Ghosh). The House of Lords ruling in Norris v USA found that price fixing was not dishonest by those standards in common law prior to the enactment of the Enterprise Act 2002, and that there had been no evidence of a discernable shift in public perceptions since the Second World War. A 2007 public survey suggests that relatively weak public attitudes to price fixing persist in the years following the introduction of the criminal offence; only 1 in 4 respondents strongly agreed that price fixing was dishonest and only 1 in 10 felt imprisonment was an appropriate sanction. It was thought that incorporating the moral element of 'dishonesty' into the offence would harden public attitudes. However, this has not happened in the absence of regular convictions and may be problematic because dishonesty necessitates a contemporary moral judgement on the part of the jury and therefore relies on attitudes being sufficiently hardened in the first place.

In principle, the prosecutor should have no difficulty convincing a jury that cartel conduct was dishonest - especially where efforts were made to hide an agreement from customers. In practice, however, prosecutors may be discouraged from bringing cases to trial that are unlikely to yield a guilty plea. Most future UK cases are likely to result from international infringements, under the shadow of US antitrust enforcement. These defendants are more likely to plead guilty under the threat of extradition to the US, where the maximum penalty for price fixing is now ten years in prison. A low number of these 'safe' cases may have little increased deterrent effect on individual decision makers, especially in relation to domestic infringements. It may even prompt some to question the legitimacy of criminalisation altogether; as with Norris, defendants may come to be viewed by the business community and the press as victims of overzealous US antitrust enforcement.

The success of US enforcement is helped greatly by the high degree of certainty for firms wishing to self-report an infringement. In the absence of 
effective coordination of civil and criminal leniency programmes in Europe, increased criminal enforcement on the national level may risk discouraging leniency applications to the European Commission. Higher sanctions encourage the self-reporting of infringements in the US because the corporate immunity prize automatically extends to the revealing firm's employees. In Europe, there have been moves to consolidate national and EU leniency programmes, but immunity from criminal prosecution remains a separate issue. The OFT would also benefit from clarifying its policy on no-action letters. The certainty and speed of criminal cartel enforcement in the US is also greatly enhanced by the use of plea bargains. Although informal and discretionary forms of settlement exist in the UK, there is no comparable form of conclusive direct settlement.

Even once criminal convictions are secured, there is a question as to whether these will enhance deterrence if custodial sentences do not become the norm. The high potential benefits from a cartel infringement and the purportedly low detection rates must be met with a severe sanction, especially as this also makes detection through leniency applications more likely. The anecdotal evidence of cartelists securing reemployment at the top level reflects their value as human capital and may demonstrate a weak social stigma attached to price fixing within the business community. It is important that Director Disqualification Orders and similar innovations supplement the deterrent effects of imprisonment and may help to change attitudes within industry.

Ultimately, the long-term success of the UK criminal offence may hinge on the competition authority's ability to increase public awareness and understanding of cartels, their harmful effects and of prosecutions. This should serve to encourage normative compliance and give prosecutors the confidence to bring more criminal cases to trial. However, challenging attitudes and rousing interest are no easy task, especially given the difficulty of identifying harm, the existence of an efficiency defence for firms and the amoral nature of leniency programmes. The OFT is certainly making strong efforts under John Fingleton to keep cartel issues in the public eye - so much so that the regulator had to pay $£ 100,000$ to the supermarket Morrisons, in settlement of a defamation case, 
following premature comments about the company's alleged guilt. ${ }^{133}$ It is also notable that the first criminal convictions failed to attract any more media coverage than a corporate fine would typically do, despite its significance.

133 'OFT pays damages to Morrisons over dairy price-fixing claim' The Times, London 23 April 2008 
Appendix 1: Individuals Imprisoned for International Cartel Offences under the Sherman Act ${ }^{134}$

\begin{tabular}{|c|c|c|c|c|c|c|c|}
\hline$\sum_{\Sigma}^{W}$ & 采 & 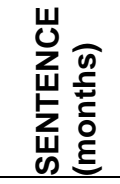 & 点 & 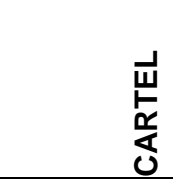 & 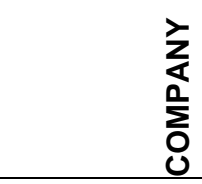 & $\begin{array}{l}z \\
\text { 을 } \\
\text { C. } \\
\text { O }\end{array}$ & 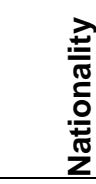 \\
\hline Kuno Sommer & 1999 & 4 & YES & Vitamins & $\begin{array}{l}\text { Hoffmann-La } \\
\text { Roche }\end{array}$ & $\begin{array}{l}\text { Managing } \\
\text { Director }\end{array}$ & $\mathrm{CHE}$ \\
\hline $\begin{array}{l}\text { Roland } \\
\text { Brönnimann }\end{array}$ & 1999 & 5 & YES & Vitamins & $\begin{array}{l}\text { Hoffmann-La } \\
\text { Roche }\end{array}$ & $\begin{array}{l}\text { President of } \\
\text { Division }\end{array}$ & $\mathrm{CHE}$ \\
\hline Andreas Hauri & 2000 & 4 & YES & Vitamins & $\begin{array}{l}\text { Hoffmann-La } \\
\text { Roche }\end{array}$ & $\begin{array}{l}\text { Division } \\
\text { Marketing Dir. }\end{array}$ & $\mathrm{CHE}$ \\
\hline $\begin{array}{l}\text { Reinhard } \\
\text { Steinmetz }\end{array}$ & 2000 & 3.5 & YES & Vitamins & BASF & $\begin{array}{l}\text { President of } \\
\text { Division }\end{array}$ & DEU \\
\hline Hugo Strotmann & 2000 & 3 & YES & Vitamins & BASF & $\begin{array}{ll}\text { Group } & \text { Vice } \\
\text { President } & \\
\end{array}$ & DEU \\
\hline Dieter Suter & 2000 & 3 & YES & Vitamins & BASF & $\begin{array}{ll}\text { President } & \text { of } \\
\text { Division } & \end{array}$ & $\mathrm{CHE}$ \\
\hline $\begin{array}{ll}\text { Micheal } & \mathrm{D} \\
\text { Andreas } & \\
\end{array}$ & 2000 & $36^{*}$ & NO & Lysine & ADM & $\begin{array}{ll}\text { Executive } & \text { Vice } \\
\text { President, } & \\
\end{array}$ & USA \\
\hline Mark Whitacre & 2000 & 30 & NO & Lysine & ADM & $\begin{array}{l}\text { President of } \\
\text { Division }\end{array}$ & USA \\
\hline $\begin{array}{l}\text { Terrance } \quad \text { S } \\
\text { Wilson }\end{array}$ & 2000 & $36^{*}$ & NO & Lysine & ADM & $\begin{array}{l}\text { Group Vice Pres. } \\
\text { and Pres. of } \\
\text { Division }\end{array}$ & USA \\
\hline Robert J Hart, & 1999 & 9 & YES & $\begin{array}{l}\text { Graphite } \\
\text { Elect. }\end{array}$ & UCAR Int. & $\begin{array}{ll}\text { Senior } & \text { Vice } \\
\text { President } & \\
\end{array}$ & USA \\
\hline Robert Krass & 1999 & 17 & YES & $\begin{array}{l}\text { Graphite } \\
\text { Elect. }\end{array}$ & UCAR Int. & President & USA \\
\hline Patrick Stainton & 2002 & 3 & YES & $\begin{array}{l}\text { MCAA } \\
\text { Chem. }\end{array}$ & Elf & Head of Division & FRA \\
\hline $\begin{array}{l}\text { Jacques } \\
\text { Jourdan }\end{array}$ & 2002 & 3 & YES & $\begin{array}{l}\text { MCAA } \\
\text { Chem. }\end{array}$ & Elf & Executive & FRA \\
\hline $\begin{array}{ll}\text { A } & \text { Alfred } \\
\text { Taubman } & \\
\end{array}$ & 2002 & 12 & NO & $\begin{array}{l}\text { Auction } \\
\text { Houses }\end{array}$ & Sotheby's & Chairman & USA \\
\hline $\begin{array}{l}\text { Erik Anders } \\
\text { Broström }\end{array}$ & 2002 & 3 & YES & $\begin{array}{l}\text { MCAA } \\
\text { Chem. }\end{array}$ & Akzo Nobel & $\begin{array}{l}\text { Manager of } \\
\text { Division }\end{array}$ & SWE \\
\hline Erik Nilsen & 2003 & 3 & YES & $\begin{array}{l}\text { Tanker } \\
\text { Shipping }\end{array}$ & $\begin{array}{l}\text { Odfjell } \\
\text { Seachem }\end{array}$ & Vice President & NOR \\
\hline Bjorn Sjaastad & 2003 & 4 & YES & $\begin{array}{l}\text { Tanker } \\
\text { Shipping }\end{array}$ & $\begin{array}{l}\text { Odfjell } \\
\text { Seachem }\end{array}$ & $\begin{array}{l}\text { Chief Executive } \\
\text { Officer }\end{array}$ & NOR \\
\hline $\begin{array}{l}\text { Hendrikus Van } \\
\text { Westenbrugge }\end{array}$ & 2004 & 3 & YES & $\begin{array}{l}\text { Tanker } \\
\text { Shipping }\end{array}$ & JO Tankers & $\begin{array}{l}\text { Co-Managing } \\
\text { Director }\end{array}$ & NLD \\
\hline Hitoshi Hayashi & 2004 & 3 & YES & Sorbates & Daicel C.I. & $\begin{array}{l}\text { Executive } \\
\text { Salesman }\end{array}$ & JPN \\
\hline Wolfgang Koch & 2005 & 4 & YES & $\begin{array}{l}\text { Rubber } \\
\text { Chem. }\end{array}$ & Bayer & Product Manager & DEU \\
\hline Heinrich Florian & 2004 & 6 & YES & DRAM & Infineon AG & $\begin{array}{l}\text { Vice Pres. Sales } \\
\& \text { Marketing }\end{array}$ & DEU \\
\hline Günter Hefner & 2004 & 5 & YES & DRAM & Infineon AG & Vice Pres. Sales & DEU \\
\hline Peter Schaefer & 2004 & 4 & YES & DRAM & Infineon NA & $\begin{array}{l}\text { Vice President } \\
\text { Marketing }\end{array}$ & DEU \\
\hline T. Rudd Corwin & 2004 & 4 & YES & DRAM & Infineon NA & $\begin{array}{l}\text { Vice Pres. Sales } \\
\& \text { Marketing }\end{array}$ & USA \\
\hline Thomas Quinn & 2006 & 8 & YES & DRAM & $\begin{array}{l}\text { Samsung } \\
\text { Semicon. }\end{array}$ & $\begin{array}{l}\text { Vice President, } \\
\text { Marketing }\end{array}$ & USA \\
\hline $\begin{array}{l}\text { Young Hwan } \\
\text { Park }\end{array}$ & 2006 & 10 & YES & DRAM & $\begin{array}{l}\text { Samsung } \\
\text { Semicon. }\end{array}$ & $\begin{array}{ll}\text { Vice } & \text { President, } \\
\text { Sales } & \\
\end{array}$ & KOR \\
\hline
\end{tabular}

${ }^{134}$ Collated from press releases and selected case filings available on the US Department of Justice, Antitrust Division website at http://www.usdoj.gov/atr/ accessed 20 Oct 2008 


\begin{tabular}{|c|c|c|c|c|c|c|c|}
\hline Sun Woo Lee & 2006 & 8 & YES & DRAM & $\begin{array}{l}\text { Samsung } \\
\text { Semicon. }\end{array}$ & $\begin{array}{l}\text { Sen. Manager } \\
\text { DRAM Sales }\end{array}$ & KOR \\
\hline Yeongho Kang & 2006 & 7 & YES & DRAM & $\begin{array}{l}\text { Samsung } \\
\text { Semicon. }\end{array}$ & $\begin{array}{lr}\text { Assoc. } & \text { Dir. } \\
\text { DRAM Marketing }\end{array}$ & KOR \\
\hline Young Woo Lee & 2006 & 7 & YES & DRAM & $\begin{array}{l}\text { Samsung } \\
\text { Semicon. }\end{array}$ & $\begin{array}{l}\text { Sales Director, } \\
\text { Germany }\end{array}$ & KOR \\
\hline D.S. Kim & 2006 & 8 & YES & DRAM & Hynix & $\begin{array}{l}\text { Gen Manager, } \\
\text { Worldwide Sales }\end{array}$ & KOR \\
\hline C.K. Chung & 2006 & 7 & YES & DRAM & Hynix & $\begin{array}{l}\text { Director, Glob. } \\
\text { Strategic Sales }\end{array}$ & KOR \\
\hline K.C. Suh & 2006 & 6 & YES & DRAM & Hynix & $\begin{array}{l}\text { Sen. Manager, } \\
\text { Marketing }\end{array}$ & KOR \\
\hline C.Y. Choi & 2006 & 5 & YES & DRAM & Hynix & $\begin{array}{l}\text { Gen. Manager, } \\
\text { Marketing, Sales }\end{array}$ & KOR \\
\hline II Ung Kim & 2007 & 14 & YES & DRAM & $\begin{array}{l}\text { Samsung } \\
\text { Semicon. }\end{array}$ & $\begin{array}{l}\text { Vice President, } \\
\text { Marketing }\end{array}$ & KOR \\
\hline Christian Caleca & 2007 & 14 & YES & $\begin{array}{l}\text { Marine } \\
\text { Hoses }\end{array}$ & $\begin{array}{l}\text { Trelleborg } \\
\text { Industrie }\end{array}$ & President & FRA \\
\hline $\begin{array}{l}\text { Jacques } \\
\text { Cognard }\end{array}$ & 2007 & 14 & YES & $\begin{array}{l}\text { Marine } \\
\text { Hoses }\end{array}$ & $\begin{array}{l}\text { Trelleborg } \\
\text { Industrie }\end{array}$ & $\begin{array}{ll}\begin{array}{l}\text { Product } \\
\text { Manager }\end{array} & \text { Area } \\
\end{array}$ & FRA \\
\hline $\begin{array}{l}\text { Peter } \\
\text { Whittle }\end{array}$ & 2007 & 30 & YES & $\begin{array}{l}\text { Marine } \\
\text { Hoses }\end{array}$ & $\begin{array}{l}\text { PW } \\
\text { Consulting }\end{array}$ & Sole Propriator & GBR \\
\hline $\begin{array}{l}\text { Bryan } \\
\text { Allison }\end{array}$ & 2007 & 24 & YES & $\begin{array}{l}\text { Marine } \\
\text { Hoses }\end{array}$ & $\begin{array}{l}\text { Dunlop Oil \& } \\
\text { Marine Ltd }\end{array}$ & $\begin{array}{l}\text { Managing } \\
\text { Director }\end{array}$ & GBR \\
\hline David Brammar & 2007 & 20 & YES & $\begin{array}{l}\text { Marine } \\
\text { Hoses }\end{array}$ & $\begin{array}{l}\text { Dunlop Oil \& } \\
\text { Marine Ltd }\end{array}$ & $\begin{array}{l}\text { Director, Sales \& } \\
\text { Marketing }\end{array}$ & GBR \\
\hline $\begin{array}{ll}\text { Charles } & \text { J. } \\
\text { Gillespie } & \end{array}$ & 2008 & 12 & YES & $\begin{array}{l}\text { Marine } \\
\text { Hoses }\end{array}$ & $\begin{array}{l}\text { Manuli } \\
\text { Rubber Ind. }\end{array}$ & $\begin{array}{l}\text { Regional } \\
\text { Manager, Sales }\end{array}$ & USA \\
\hline Keith Packer & 2008 & 8 & YES & Air Cargo & $\begin{array}{l}\text { British } \\
\text { Airways }\end{array}$ & $\begin{array}{l}\text { Comm. Gen. } \\
\text { Manager, Cargo. }\end{array}$ & GBR \\
\hline $\begin{array}{l}\text { Bruce } \\
\text { McCaffrey }\end{array}$ & 2008 & 8 & YES & Air Cargo & $\begin{array}{l}\text { Qantas } \\
\text { Airways }\end{array}$ & $\begin{array}{ll}\text { Vice } & \text { Pres. } \\
\text { Freight. } & \end{array}$ & AUS \\
\hline Timothy Pfeil, & 2008 & 6 & YES & Air Cargo & SAS & $\begin{array}{l}\text { Dir. Sales and } \\
\text { Marketing }\end{array}$ & USA \\
\hline
\end{tabular}

